\title{
Synthesis, characterization, and evaluation of a novel inhibitor of WNT/ $\beta$-catenin signaling pathway
}

\author{
Zhao Yan ${ }^{1,2^{*}}$, Zhongling Zhu ${ }^{1,2}$, Jinghui Wang ${ }^{3}$, Jian Sun ${ }^{3}$, Yihui Chen ${ }^{3}$, Guang Yang ${ }^{3}$, Wenting Chen ${ }^{3}$ \\ and Yuheng Deng ${ }^{4^{*}}$
}

\begin{abstract}
Background: Wnt/ $\beta$-catenin signaling is a highly conserved pathway in organism evolution and is important in many biological processes. Overactivation of Wnt/ $\beta$-catenin signaling is closely related to tumor development and progression. To identify potent small molecules that can fight aberrant Wnt/ $\beta$-catenin-mediated cancer, we synthesized a novel pyrazoline derivative ( $\mathrm{N}$-(4-hydroxybenzyl)-1,3,4-triphenyl-4,5-dihydro-1 H-pyrazole-5-carboxamide, $\mathrm{BHX}$ ) to block Wnt signaling, and determined the absolute configuration of its precursor (ethyl 1,3,4-triphenyl-4,5-dihydro-1H-pyrazole5 -carboxylate). We then evaluated the inhibitory effect of $\mathrm{BHX}$ in vitro and in vivo.
\end{abstract}

Results: Cell proliferation was assessed in three human cancer cell lines (A549, HT29, and MGC803) in the presence and absence of BHX using MTS assays. BHX effectively inhibited A549, HT29, and MGC803 cell proliferation with $\mathrm{IC}_{50}$ of $5.43 \pm 1.99,6.95 \pm 0.24$, and $7.62 \pm 1.31 \mu \mathrm{M}$, respectively. BHX significantly induced apoptosis and $\mathrm{G} 1$ phase arrest in A549 and MGC803 cells. The $\beta$-catenin protein level was markedly reduced in A549 and MGC803 cells under BHX treatment. The inhibitory effect of BHX in vivo was investigated using a mouse xenograft model. A549 xenograft growth was suppressed by 50.96\% in nude mice treated continuously with $100 \mathrm{mg} / \mathrm{kg}$ BHX for $21 \mathrm{~d}$. Weight remained almost unchanged, which indicates the low toxicity of the compound.

Conclusions: Our data suggest that BHX is a new drug candidate for cancer treatment because of its potent effect on the Wnt/ $\beta$-catenin pathway and low toxicity.

Keywords: $\beta$-catenin, Cell proliferation, Inhibitor, Tumorigenesis, Wnt signaling pathway

\section{Background}

The Wnt signaling pathway is a network of proteins that are important in embryogenesis and cancer [1-4]. Wht ligands trigger at least three different intracellular signaling cascades: the canonical Wnt pathway, which results in transcriptional regulation of target genes via $\beta$-catenin; the planar cell polarity pathway, which activates the small GTPases Rho and Rac; and the Wnt-dependent calcium/protein kinase $C$ pathway [5]. Among these Wnt signaling pathways, the canonical $\mathrm{Wnt} / \beta$-catenin signaling

\footnotetext{
*Correspondence: yanzhaotj@126.com; dyh@mail.cnu.edu.cn

${ }^{1}$ Tianjin Medical University Cancer Institute and Hospital, National Clinical Research Center of Cancer, Tianjin 300060, P. R. China

${ }^{4}$ Department of Chemistry, Capital Normal University, Beijing 100048,

P.R. China

Full list of author information is available at the end of the article
}

$\beta$-catenin is phosphorylated by a destruction complex formed by proteins that include axin, adenomatous polyposis coli (APC), and glycogen synthase kinase-3 (GSK-3). The phosphorylated $\beta$-catenin becomes ubiquitylated and is targeted for degradation by proteasome. Following Wnt binding to transmembrane receptor Frizzled and low-density lipoprotein receptor-related protein 5/6, the destruction complex is inhibited, thereby terminating the phosphorylation of $\beta$-catenin by GSK-3. Unphosphorylated $\beta$-catenin accumulates in the cytoplasm and subsequently translocates to the nucleus where it binds to transcription factors, such as those belonging to the $\mathrm{T}$ cell-specific transcription factor/lymphoid enhancer-binding factor (TCF/LEF) family, and activates transcription [7].

Under pathological conditions, $\beta$-catenin escapes degradation and cells retain unregulated activation of canonical 
Wnt signaling caused by mutations in APC, axin, or $\beta$-catenin [8]. Activation of the Wnt $/ \beta$-catenin signaling pathway is important in human tumorigenesis, including colorectal cancer [9], head and neck carcinoma [10], gastric cancer [11], melanoma [12], leukemia [13], and lung cancer [14]. The Wnt/ $\beta$-catenin signaling cascade has become a major focus in cancer research. Aberrant Wnt signaling is characterized by the cytoplasmic accumulation of $\beta$-catenin and its subsequent nuclear translocation and activity [15], which suggests that $\beta$-catenin may be a potential target for drug discovery. Although several small-molecule modulators of $\mathrm{Wnt} / \beta$-catenin signaling have been identified, none of them have been tested in clinical trials [16].

The pyrazoline family has attracted attention because of the biological activity, such as anti-inflammatory activity, of its members. Certain compounds containing the pyrazoline core also show antidepressant activity [17-19] and act as multidrug resistance modulators in tumor cells [20,21]. In this study, we synthesized a novel low molecular weight pyrazoline derivative, (4S,5R)-N-(4hydroxybenzyl)-1,3,4-triphenyl-4,5-dihydro- $1 H$-pyrazole-5carboxamid (BHX), which acts as a Wnt/B-catenin signaling inhibitor. The derivative was biologically evaluated in vitro using TOPflash reporter assay (Additional file 1: Figure S1). We further evaluated the anticancer activity of BHX in vitro and in vivo. BHX may be an attractive chemotherapeutic agent because of its potent effect on the Wnt/ $\beta$-catenin signaling pathway and low toxicity.

\section{Results}

\section{Synthesis of BHX}

The 1,3-dipolar cycloaddition reaction using nitrilimines is a well-known process [22-28]. This synthesis usually generates the corresponding pyrazolines as a mixture of regioisomers [29-31], but no direct evidence is available to reveal which regioisomers are obtained in this reaction. We prepared nitrilimine 3 by dehydrogenation of aldehyde hydrazine 1 with chloramine-T [32]. In the presence of ethyl cinnamate as dipolarophile, in situ-generated diphenyl nitrilimine $\mathbf{2}$ yielded the pyrazoline. After hydrolysis of compound 4 and subsequent coupling, we obtained our target compound, BHX (Figure 1). To confirm the regiochemistry of the cycloaddition for $\Delta 2$ pyrazoline $3,{ }^{1} \mathrm{H},{ }^{13} \mathrm{C}-\mathrm{HMQC}$ and ${ }^{1} \mathrm{H},{ }^{13} \mathrm{C}-\mathrm{HMBC}$ experiments were performed. We also obtained a single crystal for compound 3 (Figure 2) to determine the absolute configuration of the cycloadduct by X-ray structural analysis, which was consistent with the results of spectral analysis.

\section{BHX inhibits cancer cell proliferation}

To characterize the in vitro activity of BHX, we used three kinds of cell lines with an overactivated Wnt signaling pathway. For each cell line, the $\mathrm{IC}_{50}$ was determined using MTS assay after $3 \mathrm{~d}$ of continuous exposure to BHX. BHX effectively inhibited human lung cancer cell line (A549), human colon cancer cell line (HT29), and human gastric cancer cell line (MGC803) cell proliferation in a dose-dependent manner, and their $\mathrm{IC}_{50}$ values were $5.43 \pm 1.99,6.95 \pm 0.4$, and $7.62 \pm 1.31 \mu \mathrm{M}$, respectively (Figure 3A). BHX showed lower inhibitory effects on normal epithelial cells (MCF-10A) (Additional file 2: Figure S2). Changes in $\beta$-catenin protein levels were determined by western blot analysis. Introduction of BHX decreased $\beta$-catenin protein levels in either A549 or MGC803 cells in a time-dependent manner.

$\beta$-Catenin is also an essential component of the cell-cell adhesion complex by binding with E-cadherin. Wnt signaling reportedly regulates E-cadherin expression [33]. Thus, repression of E-cadherin expression by Slug/ Snail or TCF/ $\beta$-catenin complex reduces cell-cell adhesion. To demonstrate the effect of BHX on E-cadherin expression, E-cadherin levels were determined by western blot assay. We found that BHX induced the increase in E-cadherin protein levels (Figure 3B).

\section{BHX causes cell apoptosis and G1 arrest}

To study BHX-induced growth inhibition, we evaluated the ability of BHX to induce A549 and MGC803 cell death by apoptosis. After treatment with $5 \mu \mathrm{mol} / \mathrm{L}$ BHX for 3 d, A549 and MGC803 cells displayed a significantly higher early apoptosis rate than those treated with the vehicle $(P<0.05)$. The early apoptosis rate of the BHX-treated A549 cells (35.5\%) was significantly higher than that of the vehicle-treated cells (1.23\%). Similarly, the early apoptosis rate of the BHX-treated MGC803 cells (37.2\%) was also significantly higher than that of the vehicle-treated cells (1.61\%). However, BHXinduced late apoptosis was not observed in A549 and MGC803 cells (Figure 4A). Thus, BHX possibly induced growth inhibition through an apoptosis-dependent mechanism in selected cancer cells. To study the mechanism by which BHX inhibited cancer cell growth, we also evaluated the changes in cell cycle progression using flow cytometry. BHX induced G1 arrest in A549 and MGC803 cell lines. This BHX-associated G1 arrest was time-dependent (Figure 4B).

\section{BHX inhibits lung cell growth in vivo}

We further investigated the inhibitory effect of BHX on A549 cell tumorigenesis in vivo using a mouse xenograft model. BALB/c mice were implanted with A549 lung cells $\left(10^{7}\right.$ cells/mouse) by subcutaneous injection. When the tumor volumes were approximately $100 \mathrm{~mm}^{3}$ to $150 \mathrm{~mm}^{3}$, the mice were randomized to receive intraperitoneal injections of vehicle or BHX at 25,50 , and $100 \mathrm{mg} / \mathrm{kg}$ for 21 consecutive days. Treatment with $100 \mathrm{mg} / \mathrm{kg}$ BHX 


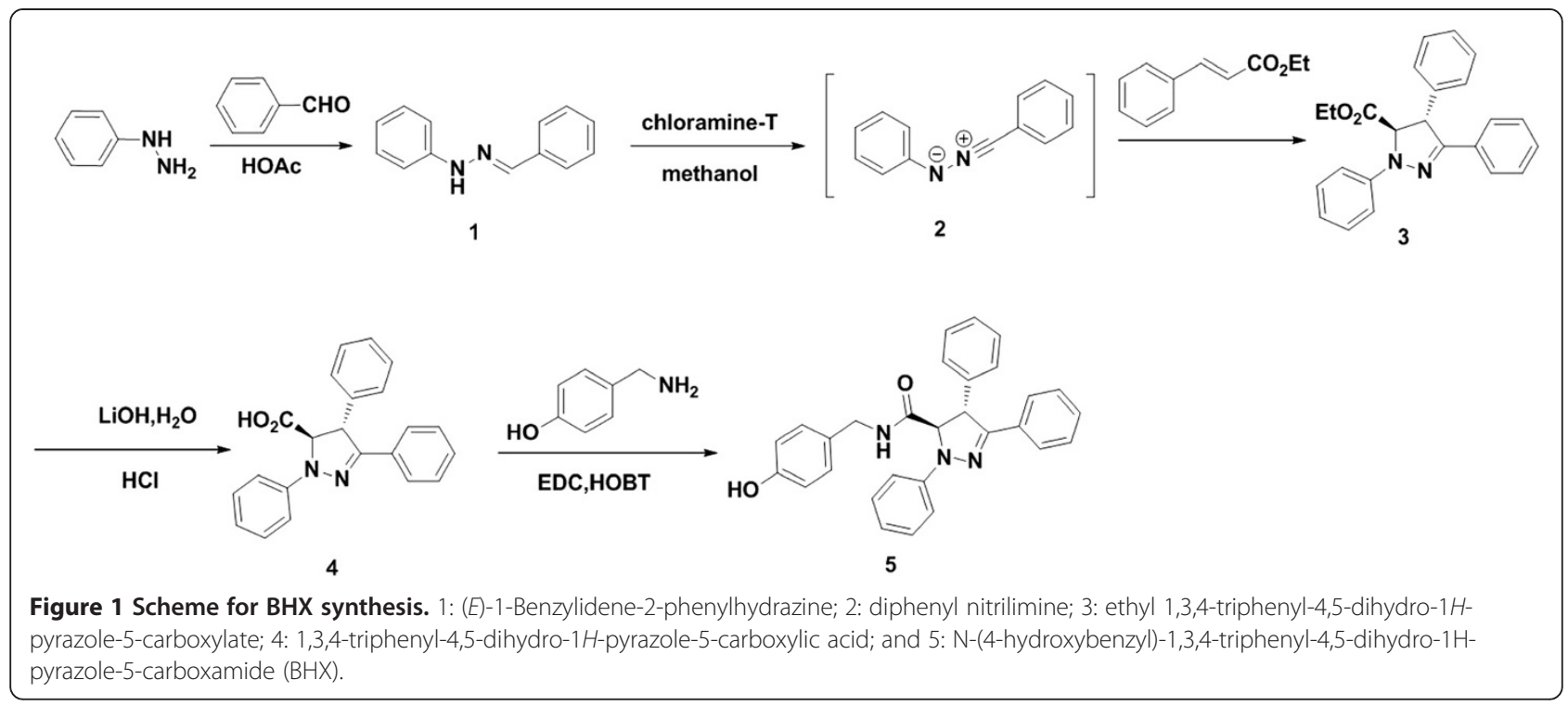

resulted in a significant reduction in tumor volume $(P<0.05$, Figure 5A) and tumor weight $(P<0.05$, Figure 5B) compared with the vehicle group. The inhibition rates in the 100 and $50 \mathrm{mg} / \mathrm{kg}$ groups were $50.96 \%$ and $29.44 \%$, respectively. By contrast, $25 \mathrm{mg} / \mathrm{kg}$ BHX had minimal effect and resulted in an inhibition rate of $10.06 \%$. No significant weight loss was observed in treatment groups or the vehicle group $(P>0.05)$, which indicates that BHX-associated toxicity was minimal (Figure $5 \mathrm{C}$ ).

\section{Discussion}

Aberrant activation of the $\mathrm{Wnt} / \beta$-catenin pathway is reportedly among the most important signal transduction pathways in the development and progression of many

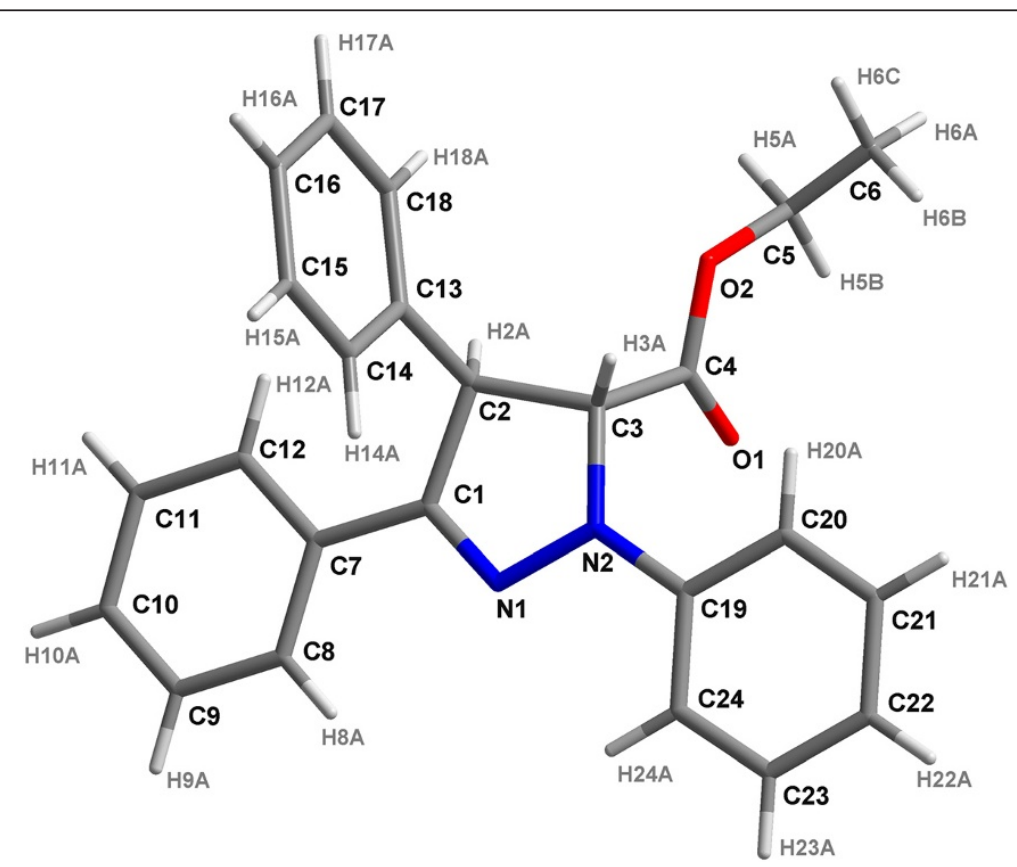

Figure $\mathbf{2}$ Crystal structure of compound 3. To confirm the regiochemistry of the cycloaddition for $\Delta 2$-pyrazoline $\mathbf{3}$, a single crystal for compound 3 was obtained. The absolute configuration was determined using X-ray structural analysis. 

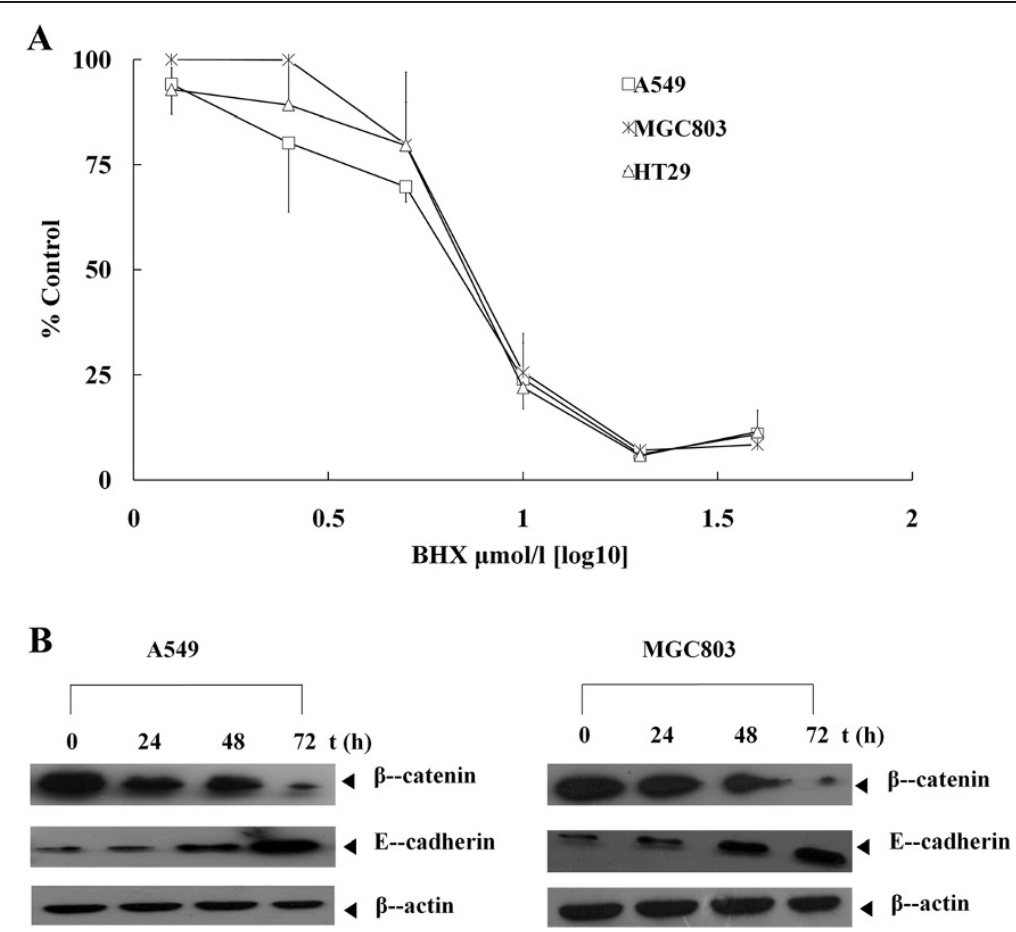

Figure 3 BHX inhibits cancer cell proliferation. (A) A549, MGC803, and HT29 cells were treated with BHX at various concentrations, and the response was determined using MTS assay. Data are presented as mean \pm SD from three independent experiments. (B) A549 and MGC803 cells were treated with $5 \mathrm{mmol} / \mathrm{L}$ BHX for $24 \mathrm{~h}$ to $72 \mathrm{~h}$. The $\beta$-catenin and E-cadherin levels were measured by western blot assay.

cancers. Thus, the inhibition of the Wnt/B-catenin signaling pathway has drawn significant interest among cancer researchers. Several molecules have been described to inhibit Wnt signaling in cells. These molecules may act at different steps in the $\mathrm{Wnt} / \beta$-catenin signal transduction pathway, such as $\beta$-catenin/TCF complex, axin 2 stability, CREB-binding protein or porcupine enzyme, and antibodies against Wnt proteins. Other inhibitors have been suggested to inhibit Wnt/ $\beta$-catenin signaling indirectly, such as non-steroid anti-inflammatory drugs and the tyrosine kinase inhibitor (Gleevac) [34]. Several compounds have been tested up to phase I/II clinical trials, but their clinical efficacy and safety have not been established.

In this study, we synthesized a novel small molecule BHX. To confirm the regiochemistry of the cycloaddition for $\Delta 2$-pyrazoline 3 , a single crystal for compound 3 was obtained and the absolute configuration was determined by X-ray structural analysis.

However, the X-ray result differed from that in a previous report [22], which indicated that the absolute stereochemistry contradicted our findings. We proposed that cycloaddition could occur from both sides of diphenyl nitrilimine, and that bond formation was favored by the $\pi, \pi$-orbital bond overlap. The transition state showed no stereoselectivity, thus, the Barluenga group, (4R,5S)-(ethyl 1,3,4-triphenyl-4,5-dihydro- $1 H$-pyrazole-5carboxylate, was obtained [35].
Then, we determined that BHX downregulated $\beta$-catenin and inhibited cancer cell tumorigenesis in vitro and in vivo. Our results show that BHX inhibited the growth of cancer cell lines by inducing G1 arrest. The mechanisms underlying the inhibition of Wnt/ $/$-catenin signaling to cause cell cycle arrest remain unclear, but the involvement of Wnt target genes c-myc and cyclin D1 in the G1-S transition may provide an answer [36-38]. Wnt signaling also requires the regulation of SKP2, which is the F-box subunit of the ubiquitinligase complex $\mathrm{SCF}^{\mathrm{SKP} 2} / \mathrm{p} 27$ degradation pathway, for Wnt signaling-mediated G1-S transition in human urinary bladder cancer cells [39]. BHX possibly has inhibitory effects on the transcriptional activities of target genes c-myc, cyclin D1, and SKP2, which can result in cell cycle arrest during the $\mathrm{G} 1$ phase.

Our results also show that BHX induced the increase in E-cadherin protein levels in A549 and MGC803 cells. E-cadherin, a prototypic member of the cadherin single-pass transmembrane glycoprotein family, regulates cell adhesion in epithelial cells in a $\mathrm{Ca}^{2+}$-dependent manner [40]. E-cadherin expression level is inversely correlated with tumorigenesis [41,42]. The loss of E-cadherin expression at cell-cell contact is consistently observed at sites of epithelial-mesenchymal transition during tumor development and progression [43]. The Wnt target gene Snail has been suggested to function as a potent repressor of E-cadherin expression [44]. The 

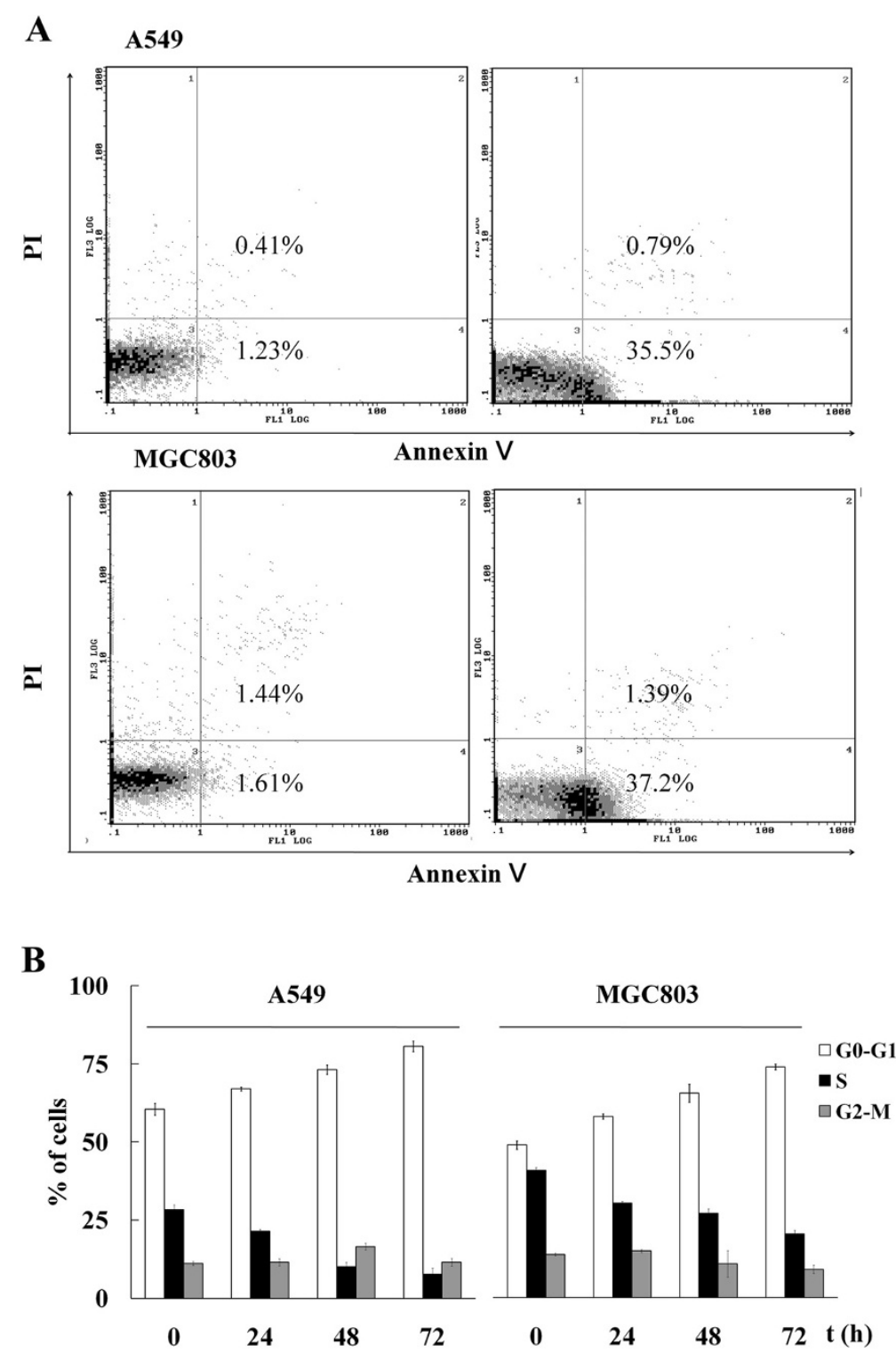

Figure 4 BHX causes cell apoptosis and G1 arrest. (A) A549 and MGC803 cells were treated with $5 \mu \mathrm{mol} / \mathrm{L}$ BHX for $72 \mathrm{~h}$. Cell apoptosis was measured using Annexin V-FITC/PI staining. (B) A549 and MGC803 cells were treated with $5 \mu \mathrm{mol} / \mathrm{L}$ BHX for $24 \mathrm{~h}$ to $72 \mathrm{~h}$. The percentage of cells in each cell cycle phase was determined by quantitation of DNA content by PI staining and flow cytometry. Data are presented as mean \pm SD from three independent experiments.

mechanism of BHX-induced E-cadherin expression is possibly related to the inhibition of the transcriptional activity of Snail.

\section{Conclusions}

In this study, BHX was synthesized, and the absolute configuration of its precursor was determined. This compound showed low nanomolar $\mathrm{IC}_{50}$ values and high inhibition rate of nude mice xenografts. Thus, BHX represents a new lead structure for the development of pharmacotherapies to treat human cancers.

\section{Materials and methods} Instrument and reagents

Nuclear magnetic resonance (NMR) spectra were obtained on a Bruker spectrometer (AV400, $400 \mathrm{MHz})$. Chemical shifts $(\delta)$ are reported in parts per million relative to residual undeuterated solvent (internal reference). The following abbreviations were used to explain the multiplicities: $\mathrm{s}=$ singlet, $\mathrm{d}=$ doublet, $\mathrm{t}=$ triplet, $\mathrm{dd}=$ doublet of doublets, $\mathrm{m}=$ multiplet, and $\mathrm{b}=$ broad. CellTiter 96 cell proliferation assay kit (MTS) was purchased from Promega (Madison, WI, USA). Rabbit anti-human $\beta$-catenin polyclonal antibody was purchased 

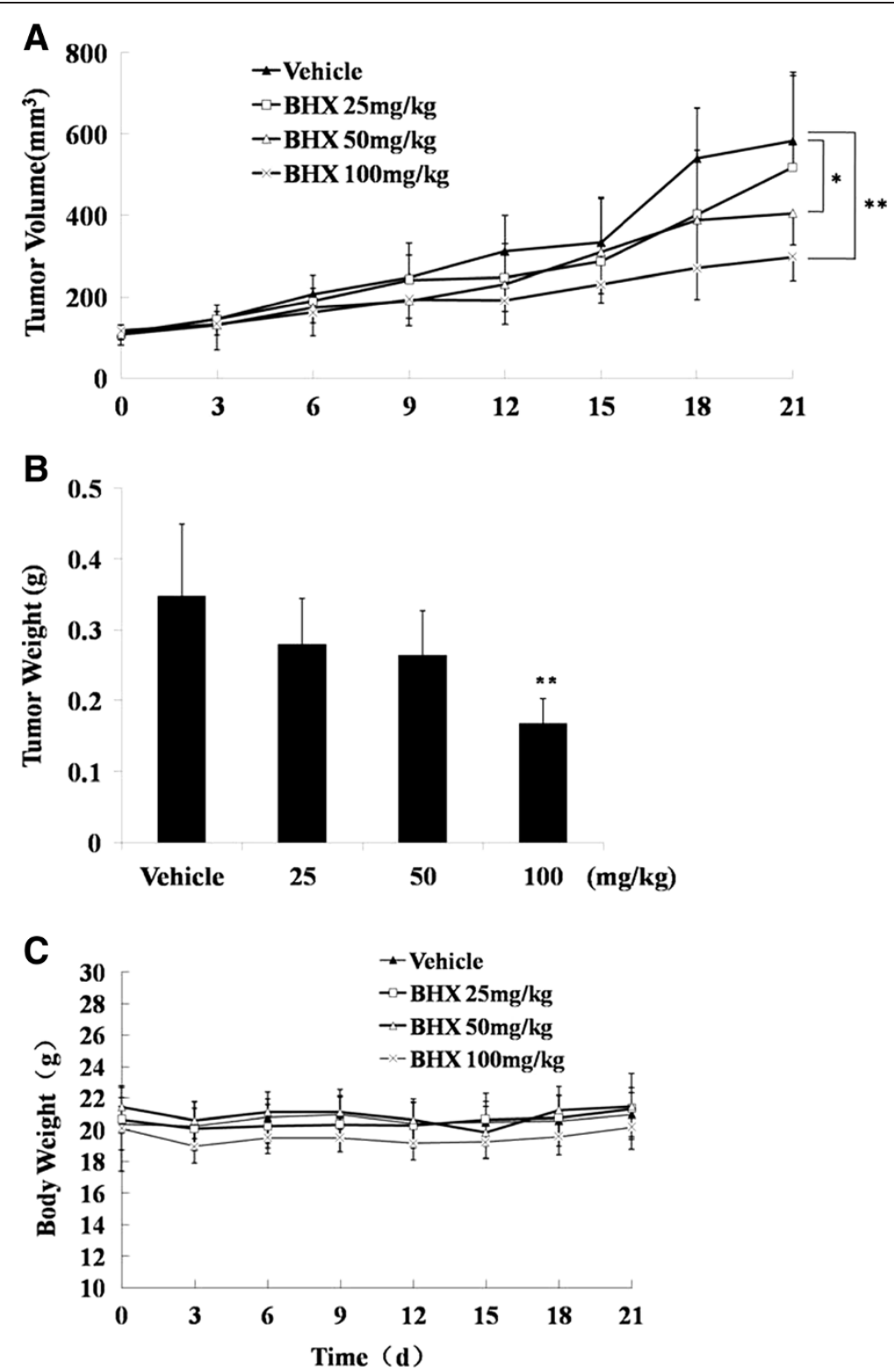

Figure 5 BHX inhibits A549 cell tumorigenesis in a xenograft model. Tumor-bearing mice were treated intraperitoneally with vehicle (DMSO) or BHX (25 and $50 \mathrm{mg} / \mathrm{kg}$ ) daily for $21 \mathrm{~d}$. Tumor size (A), tumor weight (B), and body weight (C) were measured as described in the Materials and methods section. Data are presented as mean \pm SD. ${ }^{*} P<0.05,{ }^{*} P<0.01$, significant relative to vehicle control.

from Cell Signaling Technology (Beverly, MA, USA). Rabbit anti-human E-cadherin polyclonal antibody was purchased from Santa Cruz Biotechnology (Santa Cruz, CA, USA). Annexin V-FITC apoptosis detection kit (APO-Direct) was purchased from BD Biosciences (Franklin Lakes, NJ, USA).

\section{Cells and animals}

A549, HT29, and MGC803 were obtained from ATCC (Rockville, MD, USA). A549 and MGC803 cells were cultured in RPMI 1640 culture medium supplemented with $10 \%$ fetal bovine serum (FBS, HyClone) at $37^{\circ} \mathrm{C}$ with $5 \% \mathrm{CO}_{2}$. HT29 cells were cultured in McCoy's 5A medium with $10 \% \mathrm{FBS}$ at $37^{\circ} \mathrm{C}$ with $5 \% \mathrm{CO}_{2}$. MCF-10A cells were cultured in Dulbecco's modified Eagle's medium (DMEM)/F12 culture medium supplemented with $5 \%$ equineserum (HyClone), $20 \mathrm{ng} / \mathrm{mL}$ epidermal growth factor, $0.28 \mathrm{U} / \mathrm{mL}$ insulin, $500 \mathrm{ng} / \mathrm{mL}$ hydrocortisone, and $100 \mathrm{ng} / \mathrm{mL}$ cholera toxin. Female BALB/c mice (five to six weeks old) were purchased from the Academy of Military Medical Sciences (Beijing, China). The animals were maintained under the following standardized, environmental conditions: $22^{\circ} \mathrm{C}$ to $28^{\circ} \mathrm{C}, 60 \%$ to $70 \%$ relative humidity, $12 \mathrm{~h}$ dark/light cycle, and water ad libitum. 


\section{X-ray crystallography}

Single crystals with suitable dimensions of $0.38 \mathrm{~mm} \times$ $0.32 \mathrm{~mm} \times 0.15 \mathrm{~mm}$ were mounted on glass fibers. Data collection was performed on Brucker SMART Apex CCD diffractometer by $\omega$ scan technique using graphitemonochromated Mo-Karadiation $(\lambda=0.71073 \AA)$ at $293 \mathrm{~K}$. Compound 3 was crystallized in the triclinic system, space group $P$-1 with $a=11.7328(4) \AA$, $b=12.7965(4)$ $\AA$, $c=15.5339(5) \AA, \alpha=71.355(2)^{\circ}, \beta=89.983(2)^{\circ}, \gamma=$ $68.099(2)^{\circ}$, and $V=2031.50(11) \AA^{3}$. A total of 31,926 reflections were collected from the $\theta$ range of 1.89 to 24.52, and $6750\left(\mathrm{R}_{\text {int }}=0.0315[\mathrm{I}>2(\mathrm{I})]\right) / 5079$ were unique and observed. Empirical absorption corrections were performed using SADABS. The structures were solved by direct methods (SHELXS-97) and refined by full-matrix least squares on $\mathrm{F}^{2}$ with weight scheme $w=1 /\left[\sigma^{2}\left(F_{o}^{2}\right)+\right.$ $\left.(0.2000 P)^{2}+0.0000 P\right]\left(\right.$ where $\left.\mathrm{P}=\left(\mathrm{Fo}^{2}+2 \mathrm{Fc}^{2}\right) / 3\right)$ using the SHELXL-97 program suite. All of the non-hydrogen atoms were refined anisotropically, whereas all of the hydrogen atoms were added theoretically. Crystallographic data are summarized in Table 1.

\section{(E)-1-benzylidene-2-phenylhydrazine, 1}

Benzaldehyde $(306.0 \mathrm{~g}, 2.9 \mathrm{~mol})$ was slowly added to a mixture of phenylhydrazine (312.0 g, $2.9 \mathrm{~mol})$ and glacial acetic acid $(3.1 \mathrm{~L})$. The resulting mixture was stirred at room temperature for $1 \mathrm{~h}$ and filtered. The precipitate was washed with acetic acid and $\mathrm{H}_{2} \mathrm{O}$, and then dried to obtain compound $\mathbf{1}$ as a white solid $(560.0 \mathrm{~g}$, 98.9\%). ${ }^{1} \mathrm{H}$-NMR $\left(400 \mathrm{MHz}, \mathrm{CDCl}_{3}\right) \delta: 7.65(\mathrm{~m}, 4 \mathrm{H})$, $7.36(\mathrm{~m}, 2 \mathrm{H}), 7.27(\mathrm{~m}, 3 \mathrm{H}), 7.11(\mathrm{~m}, 2 \mathrm{H})$, and $6.87(\mathrm{~m}, 1 \mathrm{H})$.

\section{Ethyl 1,3,4-triphenyl-4,5-dihydro-1H-pyrazole-5- carboxylate, 3}

A mixture of ethyl cinnamate $(19.3 \mathrm{~g}, 109.5 \mathrm{mmol})$, chloramine-T trihydrate $(48.9 \mathrm{~g}, 173.6 \mathrm{mmol})$, and compound 1 (31.9 g, $162.5 \mathrm{mmol}$ ) was dissolved in methanol $(71.8 \mathrm{~mL})$ under dim light. The resulting solution was stirred under reflux overnight. After cooling to room temperature, the reaction mixture was poured into a mixture of ethyl acetate and hexane (2.0 L, 1:1) and filtered. The filtrate was concentrated to yield the crude product as a brown oil, which was then purified by column chromatography (Hex: EtOAc, 100:1) to produce compound $2(4.2 \mathrm{~g}, 10.4 \%)$ as a white powder. ${ }^{1} \mathrm{H}$ NMR $\left(400 \mathrm{MHz}, \mathrm{CDCl}_{3}\right) \delta: 7.65(\mathrm{~m}, 2 \mathrm{H}), 7.72(\mathrm{~m}, 10 \mathrm{H})$, $7.14(\mathrm{~m}, 2 \mathrm{H}), 6.88(\mathrm{~m}, 1 \mathrm{H}), 4.79(\mathrm{~d}, 1 \mathrm{H}, J=4.3 \mathrm{~Hz}), 4.68$ $(\mathrm{d}, 1 \mathrm{H}, J=4.3 \mathrm{~Hz}), 4.22(\mathrm{~m}, 2 \mathrm{H})$, and $1.21(\mathrm{~s}, 3 \mathrm{H}, J=7.1 \mathrm{~Hz})$.

1,3,4-Triphenyl-4,5-dihydro-1 $\mathrm{H}$-pyrazole-5-carboxylic acid, 4 $\mathrm{LiOH} \cdot \mathrm{H}_{2} \mathrm{O}(0.66 \mathrm{~g}, 15.9 \mathrm{mmol})$ was added to a mixture of compound $2(3.0 \mathrm{~g}, 8.1 \mathrm{mmol})$, tetrahydrofuran (THF) (18.0 mL), $\mathrm{MeOH}(6.0 \mathrm{~mL})$, and $\mathrm{H}_{2} \mathrm{O}(6.0 \mathrm{~mL})$. The resulting solution was stirred for $1 \mathrm{~h}$ under room
Table 1 Crystallographic data and structure refinement for 3

\begin{tabular}{|c|c|}
\hline Formula & $\mathrm{C}_{24} \mathrm{H}_{22} \mathrm{~N}_{2} \mathrm{O}_{2}$ \\
\hline$\overline{F W}$ & 370.44 \\
\hline Crystal system, Space group & Triclinic, $P-1$ \\
\hline$T, \mathrm{~K}$ & $293(2)$ \\
\hline$a(\AA)$ & $11.7328(4)$ \\
\hline$b(\AA)$ & $12.7965(4)$ \\
\hline$c(\AA)$ & $15.5339(5)$ \\
\hline $\mathbf{A}\left({ }^{\circ}\right)$ & $71.355(2)$ \\
\hline$\beta\left(^{\circ}\right)$ & $89.983(2)$ \\
\hline$\gamma\left({ }^{\circ}\right)$ & $68.099(2)$ \\
\hline$V_{1} \AA^{3}$ & $2031.50(11)$ \\
\hline Z & 2 \\
\hline$D_{\text {Calc, }} M g / \mathrm{m}^{3}$ & 1.211 \\
\hline$\mu, \mathrm{mm}^{-1}$ & 0.078 \\
\hline$\theta$ range, $^{\circ}$ & $1.89 \sim 24.52$ \\
\hline Ranges of indices & $-13 \leq h \leq 13,-14 \leq k \leq 14,-18 \leq 1 \leq 18$ \\
\hline $\begin{array}{l}\text { Total reflections/unique } \\
\left(R_{\text {int }}\right) / \text { observed }\end{array}$ & $31926 / 6750(0.0315) / 5079$ \\
\hline Data/restraints/parameters & $6750 / 0 / 505$ \\
\hline Goodness of fit on $F^{2}$ & 1.094 \\
\hline$(\Delta / \sigma)_{\max }$ & 0.004 \\
\hline$\Delta \rho, \mathrm{e} \cdot \AA^{-3} \times 10^{-3}$ & $0.310,-0.338$ \\
\hline$R^{a}, w R^{b}$ & $0.0659,0.0863$ \\
\hline
\end{tabular}

temperature. The reaction mixture was concentrated, dissolved in ethyl acetate $(40.0 \mathrm{~mL})$, and then respectively washed with $5 \%$ aqueous $\mathrm{HCl}(3 \times 20 \mathrm{~mL})$ and brine $(3 \times 20 \mathrm{~mL})$. The resulting residue was dried over $\mathrm{Na}_{2} \mathrm{SO}_{4}$ and concentrated to produce compound 3 $(2.0 \mathrm{~g}, 72 \%)$ as a yellow solid. ${ }^{1} \mathrm{H}-\mathrm{NMR}(400 \mathrm{MHz}$, DMSO-d $\left.{ }^{6}\right) \delta: 13.32(\mathrm{~s}, 1 \mathrm{H}), 7.70(\mathrm{~d}, 2 \mathrm{H}, J=7.1 \mathrm{~Hz}), 7.28$ (m, 10H), 7.11(d, $2 \mathrm{H}, J=7.9 \mathrm{~Hz}), 6.83(\mathrm{t}, 1 \mathrm{H}, J=7.2 \mathrm{~Hz})$, $5.11(\mathrm{~d}, 1 \mathrm{H}, J=3.6 \mathrm{~Hz})$, and $4.68(\mathrm{~d}, 1 \mathrm{H}, J=3.7 \mathrm{~Hz})$.

\section{$\mathrm{N}$-(4-hydroxybenzyl)-1,3,4-triphenyl-4,5-dihydro-1H- pyrazole-5-carboxamide, 5}

$\mathrm{N}$-(3-Dimethylaminopropyl)-N'-ethylcarbodiimide hydrochloride (9.0 g, $45.3 \mathrm{mmol})$, 1-hydroxybenzotriazole (6.1 g, $45.3 \mathrm{mmol}$ ), and 4-(aminomethyl)phenol were added to a mixture of compound 3 (14.1 g, $41.1 \mathrm{mmol})$ in THF $(140.0 \mathrm{~mL})$. The resulting solution was stirred overnight under room temperature, and then concentrated to yield the crude product. The pure product $(10.4 \mathrm{~g}, 56.5 \%)$ was obtained by column chromatography (Hex: EtOAc, 5:1) as a pale yellow solid. ${ }^{1} \mathrm{H}-\mathrm{NMR}\left(400 \mathrm{MHz}, \mathrm{DMSO}-\mathrm{d}^{6}\right) \delta: 9.30$ (s, $1 \mathrm{H}), 8.83(\mathrm{t}, 1 \mathrm{H}, J=5.8 \mathrm{~Hz}), 7.67(\mathrm{~d}, 2 \mathrm{H}, J=7.1 \mathrm{~Hz})$, 
$7.28(\mathrm{~m}, 10 \mathrm{H}), 7.07(\mathrm{~m}, 4 \mathrm{H}), 6.82(\mathrm{t}, 1 \mathrm{H}, J=7.3 \mathrm{~Hz})$, $6.70(\mathrm{~d}, 2 \mathrm{H}, J=8.8 \mathrm{~Hz}), 4.93(\mathrm{~d}, 1 \mathrm{H}, J=4.5 \mathrm{~Hz}), 4.71$ $(\mathrm{d}, 1 \mathrm{H}, J=4.5 \mathrm{~Hz})$, and $4.21(\mathrm{~d}, 2 \mathrm{H}, J=5.6 \mathrm{~Hz})$.

\section{Cell proliferation assay}

For 3-(4,5-dimethylthiazol-2-yl)-5-(3-carboxymethoxyphenyl)2-(4-sulfophenyl)-2H-tetrazolium salt (MTS) cell proliferation assays, A549, MGC803, and HT29 cells were seeded in 96-well culture plates at a density of 500 cells to 1,000 cells per well. After $24 \mathrm{~h}, \mathrm{BHX}$ or dimethyl sulfoxide (DMSO) was added to the cells at concentrations between 1.25 and $40 \mu \mathrm{mol} / \mathrm{L}$. Cell proliferation was determined after 72 husing CellTiter 96 AQueous One Solution (Promega). Absorbance was recorded at $490 \mathrm{~nm}$ using a microplate reader.

\section{Apoptosis assays and cell cycle analysis}

Cells were seeded at approximately 50\% confluence in six-well cell culture plates. BHX $(5 \mu \mathrm{mol} / \mathrm{L})$ or DMSO was added after $24 \mathrm{~h}$, and the cells were collected after $72 \mathrm{~h}$ of incubation. Cell apoptosis was measured by Annexin V-FITC/propidium iodide (PI) staining. Cells were considered early apoptotic if Annexin $\mathrm{V}$ was positive and PI was negative, and late apoptotic if both Annexin V and PI were positive. For cell cycle analysis, cells were rinsed in PBS, fixed in 95\% ethanol, pelleted by centrifugation, and resuspended in RNase A at $50 \mu \mathrm{g} / \mathrm{mL}$. After incubation at $37^{\circ} \mathrm{C}$ for $1 \mathrm{~h}, 50 \mathrm{~g} / \mathrm{mL}$ PI was added. DNA content was determined by flow cytometry, and the proportion of cells in each cell cycle phase was determined using ModFit software.

\section{Western blot analysis}

Whole cell extracts were lysed in lysis buffer with the following components: $240 \mathrm{mmol} / \mathrm{L}$ Tris ( $\mathrm{pH}$ 6.8), 2\% sodium dodecyl sulfate (SDS), $0.5 \%$ glycerol, $5 \mathrm{mmol} / \mathrm{L}$ EDTA, $1 \mathrm{mg} / \mathrm{L}$ aprotinin, $1 \mathrm{mg} / \mathrm{L}$ leupeptin, $1 \mathrm{mg} / \mathrm{L}$ peptatin A, $10 \mathrm{mmol} / \mathrm{L} \beta$-glycerol phosphate, $1 \mathrm{mmol} / \mathrm{L}$ $\mathrm{Na}_{3} \mathrm{VO}_{4}$, and $1 \mathrm{mmol} / \mathrm{L}$ phenylmethylsulfonyl fluoride. Lysates were then spun at $12,000 \mathrm{rpm}$ for $10 \mathrm{~min}$ to remove insoluble materials. The protein concentration was measured by BCA protein assay (Pierce). Total proteins were fractionated using SDS-PAGE and transferred to a polyvinylidenefluoride membrane; blotted with antibodies against $\beta$-catenin, E-cadherin, and $\beta$-actin; and detected by enhanced chemiluminescence (Amersham Biosciences).

\section{Xenograft studies}

Female BALB/c mice, weighing $17 \mathrm{~g}$ to $23 \mathrm{~g}$, were implanted subcutaneously with $1 \times 10^{7}$ A549 cells. Tumor sizes were assessed using the two largest perpendicular axes. Tumor volume was calculated using the formula $\mathrm{V}=\left(\mathrm{a} \times \mathrm{b}^{2}\right) / 2$, where $a$ is length and $b$ is width. When tumor volumes reached $100 \mathrm{~mm}^{3}$ to $150 \mathrm{~mm}^{3}$, the mice were randomized to drug-treated or vehicle groups (six mice per group). BHX or vehicle control was administered by daily intraperitoneal injection at dose levels of 25, 50, and $100 \mathrm{mg} / \mathrm{kg}$ body weight for 21 consecutive days. Tumor growth was monitored every $3 \mathrm{~d}$ using a Vernier caliper. Tumor-bearing mice were assessed for weight loss every $3 \mathrm{~d}$. Tumors were removed from mice $21 \mathrm{~d}$ after vehicle or BHX treatment. Inhibition rates (antitumor effects) are expressed as $\mathrm{T} / \mathrm{C} \%$ (treatment groups versus control) by dividing the tumor volumes from treatment groups with the control group and then multiplying the quotient by 100 . All animal experiments were conducted in accordance with the Animal Care Committee guidelines of Tianjin Medical University Cancer Institute and Hospital.

\section{Statistical analysis}

All values are expressed as mean \pm SD. Crude data were analyzed using SPSS 16.0 statistical software. The statistical significance of differential findings between experimental groups and control was determined by Student's $t$-test or Wilcoxon's test. $P$ values $<0.05$ were considered statistically significant.

\section{Additional files}

\begin{abstract}
Additional file 1: Figure S1. BHX dramatically downregulates $\beta$-catenin /TCF-dependent transcriptional activity. To measure Wnt signaling, cells at a density of $5 \times 10^{3}$ per well were seeded into 24-well plates before transfection. TOPflash or FOPflash plasmids were co-transfected with PRL-TK plasmid (internal control). Luciferase activity was measured by Dual-Glo Luciferase Assay System after cells were cultured for $18 \mathrm{~h}$. The ratio between firefly luciferase activity (TOPflash/FOPflash) and renilla activity (internal control) was used for TCF/LEF transcription activity. Data represent mean \pm SD from three independent experiments. Numerous small molecules were screened for their ability to inhibit Wnt pathway downstream transcriptional activity using the TOP/FOP reporter assay. $\mathrm{BHX}$ was observed to reduce $\beta$-catenin/TCF-dependent transcriptional activity by 67\%. 1: DMSO; 9: BHX.

Additional file 2: Figure S2. Effect of BHX on cell growth of MCF-10A or A549. MCF-10A and A549 were plated in triplicate. After $24 \mathrm{~h}$, the cells were treated with DMSO or $3 \mu \mathrm{mol} / \mathrm{L}$ BHX. Viable cell numbers were counted daily for $4 \mathrm{~d}$ by trypan blue exclusion. Results are presented as percentage of control. Data are presented as mean \pm SD from three independent experiments.
\end{abstract}

\section{Competing interests}

The authors declare that they have no potential competing interest with respect to the research, authorship and/or publication of this article.

\section{Authors' contributions}

ZZ, JW, JS, YC, GY and WC acquired and analyzed data as; performed the statistical analysis; drafted the manuscript. ZY and YD conceived and designed the study; revised and approved the manuscript. All of the authors read and approved the final manuscript.

\section{Author details}

${ }^{1}$ Tianjin Medical University Cancer Institute and Hospital, National Clinical Research Center of Cancer, Tianjin 300060, P. R. China. ${ }^{2}$ Key Laboratory of Cancer Prevention and Therapy, Tianjin 300060, P. R. China. ${ }^{3}$ Beijing Laviana Pharmatech Co., Ltd, Beijing 102206, P. R. China. ${ }^{4}$ Department of Chemistry, Capital Normal University, Beijing 100048, P. R. China. 
Received: 22 May 2013 Accepted: 18 September 2013

Published: 7 October 2013

\section{References}

1. Kuwabara T, Hsieh J, Muotri A, Yeo G, Warashina M, Lie DC, Moore L, Nakashima K, Asashima M, Gage FH: Wnt-mediated activation of NeuroD1 and retro-elements during adult neurogenesis. Nat Neurosci 2009, 12:1097-1105

2. Lie D-C, Colamarino SA, Song H-J, Desire L, Mira H, Consiglio A, Lein ES, Jessberger S, Lansford H, Dearie AR, Gage FH: Wnt signalling regulates adult hippocampal neurogenesis. Nature 2005, 437:1370-1375.

3. Jiang X, Yu Y, Yang HW, Agar NYR, Frado L, Johnson MD: The imprinted gene PEG3 inhibits Wnt signaling and regulates glioma growth. J Biol Chem 2010, 285:8472-8480.

4. Gao H, Le Y, Wu X, Silberstein LE, Giese RW, Zhu Z: VentX, a novel lymphoid-enhancing factor/T-cell factor-associated transcription repressor, is a putative tumor suppressor. Cancer Res 2010, 70:202-211.

5. Clevers H: Wnt/beta-catenin signaling in development and disease. Cell 2006, 127:469-480.

6. Takahashi-Yanaga F, Sasaguri T: The Wnt/ $\beta$-catenin signaling pathway as a target in drug discovery. J Pharmacol Sci 2007, 104:293-302.

7. Polakis P: Wnt signaling and cancer. Genes Dev 2000, 14:1837-1851.

8. Klaus A, Birchmeier W: Wnt signalling and its impact on development and cancer. Nat Rev Cancer 2008, 8:387-398.

9. Korinek V, Barker N, Morin PJ, van Wichen D, de Weger R, Kinzler KW, Vogelstein $\mathrm{B}$, Clevers $\mathrm{H}$ : Constitutive transcriptional activation by a beta-catenin-Tcf complex in APC-/- colon carcinoma. Science 1997, 275:1784-1787.

10. Rhee CS, Sen M, Lu D, Wu C, Leoni L, Rubin J, Corr M, Carson DA: Wnt and frizzled receptors as potential targets for immunotherapy in head and neck squamous cell carcinomas. Oncogene 2002, 21:6598-6605.

11. Katoh M, Kirikoshi H, Terasaki H, Shiokawa K: WNT2B2 mRNA, up-regulated in primary gastric cancer, is a positive regulator of the WNT- betacatenin-TCF signaling pathway. Biochem Biophys Res Commun 2001, 289:1093-1098.

12. Weeraratna AT, Jiang $Y$, Hostetter G, Rosenblatt K, Duray P, Bittner M, Trent $J \mathrm{M}$ : Wnt5a signaling directly affects cell motility and invasion of metastatic melanoma. Cancer Cell 2002, 1:279-288.

13. Lu D, Zhao Y, Tawatao R, Cottam HB, Sen M, Leoni LM, Kipps TJ, Corr M, Carson DA: Activation of the Wnt signaling pathway in chronic lymphocytic leukemia. Proc Natl Acad Sci U S A 2004, 101:3118-3123.

14. Mazieres J, He B, You L, Xu Z, Jablons DM: Wnt signaling in lung cancer. Cancer Lett 2005, 222:1-10

15. Gordon MD, Nusse R: Wnt signaling: multiple pathways, multiple receptors, and multiple transcription factors. J Biol Chem 2006, 281:22429-22433.

16. Verkaar F, Zaman GJR: New avenues to target Wnt/[beta]-catenin signaling. Drug Dis Today 2011, 16:35-41.

17. Chimenti F, Bolasco A, Manna F, Secci D, Chimenti P, Befani O, Turini P, Giovannini V, Mondovì B, Cirilli R, La Torre F: Synthesis and selective inhibitory activity of 1-acetyl-3,5-diphenyl-4,5-dihydro-(1H)-pyrazole derivatives against monoamine oxidase. J Med Chem 2004, 47:2071-2074.

18. Prasad YR, Kumar PR, Deepti CA, Ramana MV: Synthesis and antidepressant activity of some 3-(3"-coumarinyl)-1,5-diphenyl-2-pyrazolines and 3-(2"-hydroxy naphthalen-1"-yl)-1,5-diphenyl-2-pyrazolines. Asian J Chem 2007, 19:4790-4798.

19. Girisha KS, Kalluraya B, Narayana V, Padmashree: Synthesis and pharmacological study of 1-acetyl/propyl-3-aryl-5-(5-chloro-3-methyl-1-phenyl-1 H-pyrazol-4-yl)2-pyrazoline. Eur J Med Chem 2010, 45:4640-4644.

20. Roecker AJ, Coleman PJ, Mercer SP, Schreier JD, Buser CA, Walsh ES, Hamilton K, Lobell RB, Tao W, Diehl RE, et al: Kinesin spindle protein (KSP) inhibitors. Part 8: design and synthesis of 1,4-diaryl-4,5-dihydropyrazoles as potent inhibitors of the mitotic kinesin KSP. Bioorg Med Chem Lett 2007, 17:5677-5682.

21. Mizuno N, Takahashi T, Kusuhara H, Schuetz JD, Niwa T, Sugiyama Y: Evaluation of the role of breast cancer resistance protein (BCRP/ABCG2) and multidrug resistance-associated protein 4 (MRP4/ABCC4) in the urinary excretion of sulfate and glucuronide metabolites of edaravone (MCI-186; 3-methyl-1-phenyl-2-pyrazolin-5-one). Drug Metab Dispos 2007, 35:2045-2052
22. Barluenga J, Fernández-Marí F, González R, Aguilar E, Revelli Gustavo A, Viado Argimiro L, Fañanás Francisco J, Olano B: a, $\beta$-unsaturated fischer carbene complexes vs. 1,3-Dipoles: reactions with nitrones and nitrilimines. Eur J Org Chem 2000, 2000:1773-1783.

23. Kano T, Hashimoto T, Maruoka K: Enantioselective 1,3-dipolar cycloaddition reaction between diazoacetates and $\alpha$-substituted acroleins: total synthesis of manzacidin A. J Am Chem Soc 2006, 128:2174-2175.

24. Simovic D, Di M, Marks V, Chatfield DC, Rein KS: 1,3-Dipolar cycloadditions of trimethylsilyldiazomethane revisited: steric demand of the dipolarophile and the influence on product distribution. $J$ Org Chem 2006, 72:650-653.

25. Miqdad OA, Abunada NM, Hassaneen HM: Regioselectivity of nitrilimines 1,3-dipolar cycloaddition: novel synthesis of spiro[4,4]nona-2,8-dien-6one derivatives. Heteroat Chem 2011, 22:131-136.

26. Li Y, Hong D, Zhu Y-X, Lu P, Wang Y: One-pot synthesis of 5-sulfonamidopyrazole from terminal alkynes, sulfonyl azides and hydrazones. Tetrahedron 2011, 67:8086-8091.

27. Girgis AS, Farag H, Ismail NSM, George RF: Synthesis, hypnotic properties and molecular modeling studies of 1,2,7,9-tetraaza-spiro[4.5]dec-2-ene6,8,10-triones. Eur J Med Chem 2011, 46:4964-4969.

28. Farag AM, Elkholy YM, Ali KA: Regioselective synthesis of diazaspiro[4.4] nona- and tetrazaspiro[4.5]deca-2,9-diene-6-one derivatives. J Heterocycl Chem 2008, 45:279-283.

29. Barluenga J, Fernández-Marí F, Aguilar E, Viado AL, Olano B: First highly regio- and diastereoselective synthesis of $\Delta 2$-pyrazolines by [3 +2 ] cycloaddition of chiral non-racemic fischer carbene complexes with nitrilimines. Tetrahedron Lett 1998, 39:4887-4890.

30. Boudriga S, Askri M, Gharbi R, Rammah M, Ciamalac K: 1,3-Dipolar cycloadditions of arylcarbonitrile oxides and diaryl nitrilimines with some 2-arylmethylene-1,3-indanediones; regiochemistry of the reactions. J Chem Res Synopses 2003, 2003:204-207.

31. Abunada NM, Hassaneen HM, Kandile NG, Miqdad OA: Synthesis and biological activity of some New pyrazoline and pyrrolo[3,4-c]pyrazole4,6-dione derivatives: reaction of nitrilimines with some dipolarophiles. Molecules 2008, 13:1011-1024.

32. He B, Fujii N, You L, Xu Z, Jablons DM: Targeting gli proteins in human cancer by small molecules. Wo Patent 2007, 2(007):067-814.

33. Conacci-Sorrell M, Simcha I, Ben-Yedidia T, Blechman J, Savagner P, Ben-Ze 'ev A: Autoregulation of E-cadherin expression by cadherin-cadherin interactions: the roles of beta-catenin signaling, slug, and MAPK. J Cell Biol 2003, 163:847-857.

34. Wang W, Liu H, Wang S, Hao X, Li L: A diterpenoid derivative 15-oxospiramilactone inhibits Wnt/beta-catenin signaling and colon cancer cell tumorigenesis. Cell Res 2011, 21:730-740.

35. Barluenga J, Fernandez-Mari F, Viado AL, Aguilar E, Olano B: First diastereoselective [3 + 2] cycloaddition of chiral non-racemic alkenyl Fischer carbene complexes with diazomethane derivatives. J Chem Soc Perkin Trans 1997, 1:2267-2268.

36. van de Wetering $M$, Sancho E, Verweij C, de Lau W, Oving I, Hurlstone A, van der Horn K, Batlle E, Coudreuse D, Haramis AP, et al: The beta-catenin /TCF-4 complex imposes a crypt progenitor phenotype on colorectal cancer cells. Cell 2002, 111:241-250.

37. Shtutman M, Zhurinsky J, Simcha I, Albanese C, D'Amico M, Pestell R, BenZe'ev A: The cyclin D1 gene is a target of the $\beta$-catenin/LEF-1 pathway. Proc Nat Acad Sci 1999, 96:5522-5527.

38. Muncan V, Sansom OJ, Tertoolen L, Phesse TJ, Begthel H, Sancho E, Cole AM, Gregorieff A, de Alboran IM, Clevers H: Rapid loss of intestinal crypts upon conditional deletion of the Wnt/Tcf-4 target gene c-Myc. Mol Cell Biol 2006, 26:8418-8426.

39. Tang Y, Simoneau AR, Liao WX, Yi G, Hope C, Liu F, Li S, Xie J, Holcombe RF, Jurnak FA, et al: WIF1, a Wnt pathway inhibitor, regulates SKP2 and c-myc expression leading to G1 arrest and growth inhibition of human invasive urinary bladder cancer cells. Mol Cancer Ther 2009, 8:458-468.

40. Tian X, Liu Z, Niu B, Zhang J, Tan TK, Lee SR, Zhao Y, Harris DC, Zheng G: E-cadherin/beta-catenin complex and the epithelial barrier. J Biomed Biotechnol 2011, 2011:567305.

41. Vos CB, Cleton-Jansen AM, Berx G, de Leeuw WJ, ter Haar NT, van Roy F, Cornelisse CJ, Peterse JL, van de Vijver MJ: E-cadherin inactivation in lobular carcinoma in situ of the breast: an early event in tumorigenesis. Br J Cancer 1997, 76:1131-1133. 
42. Perl AK, Wilgenbus P, Dahl U, Semb H, Christofori G: A causal role for E-cadherin in the transition from adenoma to carcinoma. Nature 1998, 392:190-193.

43. Cano A, Perez-Moreno MA, Rodrigo I, Locascio A, Blanco MJ, del Barrio MG, Portillo F, Nieto MA: The transcription factor snail controls epithelial-mesenchymal transitions by repressing E-cadherin expression. Nat Cell Biol 2000, 2:76-83.

44. Zhou BP, Deng J, Xia W, Xu J, Li YM, Gunduz M, Hung MC: Dual regulation of Snail by GSK-3beta-mediated phosphorylation in control of epithelial-mesenchymal transition. Nat Cell Biol 2004, 6:931-940.

doi:10.1186/1476-4598-12-116

Cite this article as: Yan et al:: Synthesis, characterization, and evaluation of a novel inhibitor of WNT/ $\beta$-catenin signaling pathway. Molecular Cancer 2013 12:116.

\section{Submit your next manuscript to BioMed Central and take full advantage of:}

- Convenient online submission

- Thorough peer review

- No space constraints or color figure charges

- Immediate publication on acceptance

- Inclusion in PubMed, CAS, Scopus and Google Scholar

- Research which is freely available for redistribution 